\title{
THE INFLUENCE OF STATE'S POLICY ON THE DEVELOPMENT OF THE GEOMETRY OF PREMISES ON EXAMPLE OF THE EVOLUTION OF RUSSIA HOUSING
}

\author{
WPŁYW POLITYKI PAŃSTWA NA ROZWÓJ GEOMETRII POMIESZCZEŃ \\ NA PRZYKŁADZIE EWOLUCJI ROSYJSKIEGO MIESZKANIA
}

\author{
Volodymyr Durmanov \\ prof. dr hab. inż. arch. \\ Author's Orcid number: 0000-0002-2296-2310 \\ Bialystok University of Technology \\ Department of Architecture \\ Unit for Architecture of Local Cultures
}

\begin{abstract}
The direction of housing development results from changes in the spatial consciousness of the society. The article, based on historical studies of Russian housing, hypothesizes that the development of the geometry of living quarters is characterized by cyclical changes. The spatial image of living premises as the basis of its reproduction is influenced by informational factors: external inherent in the global design technology existing at a certain historical time, and internal, arising from the experience gained as a result of local construction. Both information streams change the state of political awareness that determines the direction of structural changes in the physical environment until they are effectively used.
\end{abstract}

Key words: living premises, spatial image, urban policy, housing, Russia.

\section{STRESZCZENIE}

Kierunek rozwoju mieszkań wynika ze zmian w świadomości przestrzennej społeczeństwa. W artykule, opartym na historycznych badaniach rosyjskich mieszkań, przedstawia się hipotezę, że rozwój geometrii pomieszczeń mieszkalnych charakteryzuje się cyklicznymi zmianami. Na przestrzenny wizerunek mieszkania jako podstawę jego reprodukcji, wpływają zewnętrzne czynniki informacyjne: zewnętrzne - właściwe dla istniejącej w pewnym historycznym czasie globalnej technologii projektowania oraz wewnętrzne, powstające z doświadczenia uzyskanego w wyniku lokalnego budowania. Obydwa strumienie informacji zmieniają stan świadomości politycznej, który określa kierunek strukturalnych zmian w środowisku fizycznym do czasu ich efektywnego wykorzystania.

Słowa kluczowe: lokale mieszkalne, obraz przestrzenny, polityka miejska, mieszkanie, Rosja. 


\section{INTRODUCTION. DISCUSSIONS}

It is known that for a significant part of our life we have to adapt to a changeable external environment. Changing the properties and geometry of the environment affects our well-being and health no less than the processes occurring inside us. Presumably, the awareness of the relative stability of the properties and geometry of some natural containers (caves, grottoes, tree crowns, etc.) allowed people to learn how to reproduce them artificially. The buildings and structures created did not always serve for a long time. The necessity forced to build new or transform old premises, when, due to the loss of suitability, they had to be destroyed or abandoned. Observing the dynamics of the characteristics of the artificial premises of modern states allows us to assert that the pace and forms of their geometric transformation are accelerating and expanding.

In the second half of the last century, significant changes took place in the housing policy of many countries, which affected the change in the ownership structure of construction enterprises and the technology of urban planning and architectural design. Subsequent experience in the operation of the constructed residential premises revealed several disadvantages associated with their consumption (deterioration in the health of the population associated with overcrowding of residence; the need for constant change of places of residence caused by the dynamics of life cycles; the growing number of empty and abandoned buildings, etc.). The diversity and variety of geometric forms of the created living environment stimulated the development of their research in all countries (Alexander C., Altman I., Baum A., Bechtel R., Cambell D., Davis W., Gale N., Herzog T., Kaplan R., Kaplan S., Lang J., Maslow A., Mintz N., Nasar J., Parsons R., Russell J., Steinitz C., Urlich R., Worchel S., Zejsel J. and other). In the early 1980s, some psychologists and architects joined forces in conducting large-scale surveys of urban residential premises, creating a Moscow-Tallinn group of researchers (Kartashova - Heidmets), which made it possible to formulate the main approaches to determining their qualities. Historical events at the end of the last century and the beginning of the new century did not allow presenting the results of these studies in exterior scientific publications, although many conclusions were reflected in subsequent Russian-speaking dissertations (Albanov S., Barmaszyna L., Zabruskowa M., Koloskov V., Kruusvall J., Menshykova E., Molczanov V., Niit T., Ovsiannikov V., Ovsiannikova N., Orlov P., Smotrikowskij V., Volov V., и др.). The studies carried out also made it possible to establish the concept of living premises as a subject of interdisciplinary research and its spatial or geometric image as a genetic basis for its reproduction that presented on all stages of production and consumption of dwellings.

The term living premises or living quarters became actively used in sociological and statistical research after the Second World War. It usually defines as the structurally separated internal parts of buildings that are used or intended for human habitation. An expanded interpretation of this concept covers a wide range of geometric shapes of premises - from rooms to the other capacities connected with its which create the unified subject of consumption. The variety of premises allows them to be classified according to the degree of isolation from the living environment, time of use, mobility, etc. Unlike the concept of living space, which is described as a wide range of subjective and objective phenomena associated with the residence of people, living premises reflects ideas about its material three-dimensional properties and geometric characteristics.

Before the appearance of the first artificially created premises, their evolutionary forms and shapes were represented by a wide range of open and semi-open territorial shapes of temporary stay. The first artificial ephemeral living premisses made of mammoth bones appeared on the territory of modern Ukraine about 20 thousand years ago (Pidoplichko, 1969). The surviving remains of ancient urban dwellings dating back to the formation of the early states testify to the huge territorial diversity of building materials and technologies from which they were built. Even within the boundaries of one cultural area, significant differences are found in the size of the rooms and their spatial organization (Baker, 2014). Despite the huge variety of dwellings, comparable to the uniqueness of all the living households, in every socio-territorial community, one can find fairly stable geometric features of premises that persist during a rather long stage of cultural development, which in this study is called its spatial image.

The main characteristics of the spatial image of dwelling premises usually its area, the number of rooms, organization and the features of equipment and furniture. Revealing the properties of 
the spatial image of a dwelling, represented by its variability and ability to reflect the direction of changes in the life of communities, is one of the tasks of architectural science. The practical value of such research is usually associated with the improvement of the architectural design process.

The spatial image of living premises, represented by the products of material and spiritual activities, is an ideal phenomenon that combines the objective and subjective world due to the unity of the metric and topological nature of space. In architectural design, the spatial image of premises, as a kind of initial idea of how to transform a place of residence to ought to achieve the desired result, goes through several stages of concretization, using certain external means and energy resources. This process ends with the creation of an image of specific construction, which, in the process of subjective consumption, gradually develops a new attitude towards it with the help of abstract concepts. The process of concretization and abstraction are two of the most important, but not the only processes involved in transforming the original premises. Lifting from general characteristics to specific ones and the reverse process of movement from single and random to highlighting the most essential all-common features in the spatial image of premises are also accompanies the design process at all its stages.

In the presented study, the main attention is paid to the influence of individual and collective experience on the transformation of the spatial image of a dwelling. The experience acquired by a specific socio-demographic group associated with living in dwellings of the same geometric parameters may differ due to regional differences in life activity. At the same time, the impact of the results of construction production implemented in one technological environment can also have an impact on another. Both processes associated with the assimilation and planning of the results of construction activities, implemented under the influence of "external" and "internal" experience, can adjust the direction of architectural design.

The purpose of the article is to argue the assertion that the cyclical nature of qualitative changes in the geometric characteristics and properties of the dwelling depends on the periodic change in the parameters of the spatial image of the living premises, which reflect the attitude towards the collective and personal experience of design. The mutual and simultaneous impact of universal spatial representations arising in society under the influence of global changes and local practical experience formed in specific territorial conditions is difficult to substantiate by methods of statistical analysis of residential premises, which has only recently become the goal of periodic inventories of housing in Russia. However, assumptions about the existence in process of architectural design spatial regularities can improve the quality of future housing.

\section{CYCLICAL DYNAMICS OF THE GEOMETRICAL CHARACTERISTICS IN THE SPATIAL IMAGE OF LIVING PREMISES IN THE RUSSIAN CONSTRUCTION}

The unfavourable climate for the development of the rural economy in Eastern Europe did not contribute to the development of the social structure of communities, which reflected in the formation of the simple and fairly universal image of the traditional Russian dwelling. The technology for the production of large planed boards and logs, developed before the advent of agricultural activity (Lehmann, 1998), made it possible to erect rectangular in shape, small in area, one-room semiunderground buildings covered with a thick layer of earth on top of wooden beams (Terpilovsky, 1994). The room was heated by a hearth placed in clay or stone stoves, the smoke from which usually escaped through small windows in the wall or through a hole in the roof, which was closed at night (Rappoport, 1993). Typically, these ovens occupied 3 to $10 \%$ of the area of the room. In the 9th century, similar dwellings, which served as a shelter from the winter cold for large agrarian households, spread throughout Eastern Europe and existed in some rural settlements until the beginning of the last century. In addition to the features of the placement and size of the furnaces, regional differences were observed in the level of placement of the floor of the room, the method of joining the logs, and the features of the roof structure (Blomkwist, 1956).

The variety of dwellings increased in this territory during the period of the spread of monotheistic religious beliefs. Byzantium, driven out of the Middle East by the Arab Caliphate, faced the threat of attack also from the new states that had appeared in Western Europe. As a result of its political 
support, a significant part of the principalities inhabiting the territory of the East European Plain, united into a large social entity called "Kievan Rus", whose territorial and social resources could be compared with the Kingdom of the Franks. The close informational connection between Kyiv and Constantinople influenced the local production of dwelling. The active introduction of the Byzantine technology of stone construction contributed to the emergence of buildings, the walls of which were built of bricks bound with cement mortar. The use of new technology has proven to be difficult and time-consuming. It turned out to be impossible to erect such buildings in winter due to the freezing of the cement mortar. For the rooms in the stone house to remain warm during the night, their walls had to be more than a meter thick. Stone buildings in conditions of one and a half meter of soil freezing also required in-depth placement of foundations. The introduction of stone construction technology in the construction of dwellings increased its energy intensity, causing an expansion of the logistic area associated with the involvement of the human resources of the subject principalities in the activities. This significantly weakened the central government and could become one of the reasons for the collapse of the Kyiv state.

It is not possible to substantiate the degree of influence of architectural those policy on the viability of states of that period, based on the limited amount of available historical information. Resistance to fires of stone construction had been allowing residential buildings to be placed more compactly. Unlike Western European medieval urban dwellings, in which stone was widely used, in Eastern Europe, premises formed in brick buildings were mainly intended for the elite and became a sign of social status. During this period, the appearance of urban residential buildings gradually began to differ from the traditional rural.

Urban residential buildings of Kievan Rus have not survived, but, thanks to ancient chronicles, it is assumed that the variety of geometric characteristics of buildings was expanded due to a combination of the borrowed technology of stone and traditional wood frame construction, creating the new spatial image that permits increased in the number of stories and the number of rooms. However, the scale of urban construction remained insignificant, which had been little effect on the lifestyle of the population engaged in agriculture predominantly.

The warming of the climate in the Middle Ages caused the expansion of the Gobi Desert. The scattered nomadic tribes that inhabited the Mongolian plateau found themselves in a food crisis, which forced them to look for new livelihoods, trying to conquer large cities to seize their material resources. After the capture of parts of Eastern Europe by Mongol troops in 1240, a significant number of Slavic states came under political and economic pressure. Construction on this territory practically ceased during this period. The desire to resist the loss of independence in some principalities took place in social transformations (the emergence of the Novgorod and Pskov republics), which led to the intensification of craft and construction activities. On the territory of the feudal Slavic cities, a new form of living quarters appeared called the "Kremlin" (a defensive complex of buildings with administrative, religious premises and dwellings). In the late Middle Ages, the high degree of spatial autonomy and isolation of this multifunctional building allowed the urban population to maintain its sovereignty. After a century of construction of small premises, caused by a decrease in the volume of construction products and an increase in the density of living, a new type of spatial image of a dwelling determined the direction of its further development.

The need to strengthen the defences of the states stimulated the emergence of various forms of institutionalized dwellings. A significant historical event was the transfer of the residence of Orthodox metropolitans from the monastery to the Moscow Kremlin. This allowed the Grand Duke Dmitry Donskoy in 1325, under the banner of preserving Orthodoxy, to lead the anti-Horde coalition and expand the ring of fortified monasteries around the capital, creating a new political centre of the country from it. The high social activity inside the living quarters of the Kremlin required an increase in their dimensions. The use of the technology of vaulted arches, adopted from the Byzantine building experience in the construction of cross-domed vaults, turned out to be laborious. Meanwhile, in Western Europe, as a result of the need for the development of high-rise buildings, the spatial image of the Roman basilica was improved by using the technology of using stone frame structures. Tsar Ivan III (1440-1505), realizing the importance of applying new technology, had invited wellknown European civil engineers to strengthen the Moscow Kremlin. A new type of fired brick, light- 
er in weight and with a more accurate geometric shape, increased the speed of construction and reduced energy costs. The spatial image of the living quarters of an elite urban-dwelling became more diverse (Fig. 1).

Strengthening the centralized power of the Moscow state by changing the socio-spatial organization of cities made it possible to expand its territory, the size of which had exceeded the area occupied by independent states of Western Europe. The development of new lands was accompanied by the expansion of building experience and the emergence of special forms of dwellings for artisans and merchants. For several decades, residential settlements located on the deserted shores of the northern seas and Siberia acquired new forms, sizes and properties.

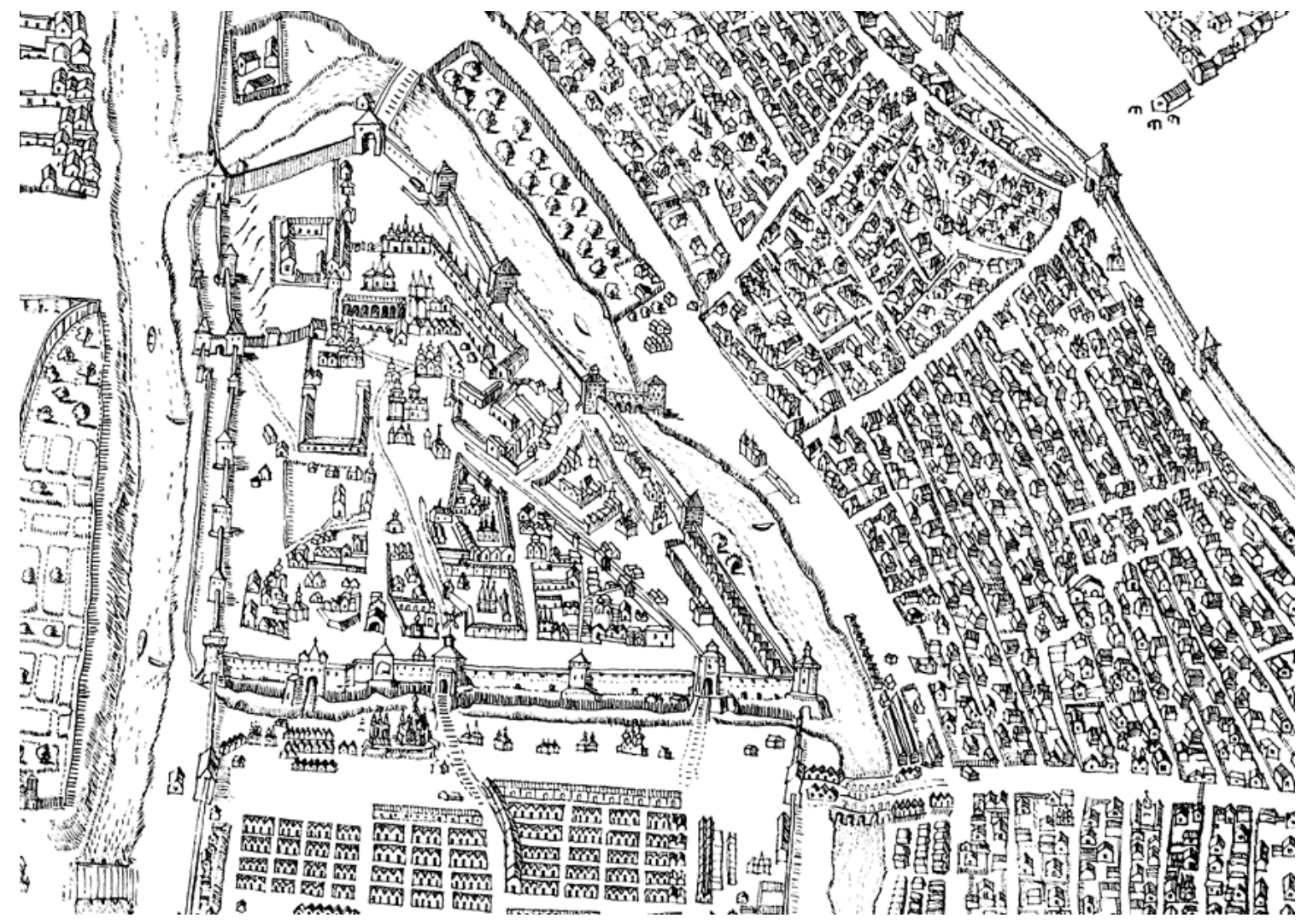

Fig. 1. The central part of Moscow by the drawing from the end XVI century. Source: (Bunin,1979)

Ryc. 1. Centralna część Moskwy na rycinie z końca XVI wieku. Źródło: (Bunin, 1979)

At the same time, in western Europe, political competition has led to significant social and technical transformations. Trade and manufacturing activity, enhanced by the activities of financial institutions, contributed to the emergence of a universal urban dwelling. The discovery of universal laws in nature created confidence in one evolutionary direction of social development. There was confidence that the construction of the "Florentine palazzo of the banker" with its developed planning structure of living quarters is the most suitable form of residence for the new financial elite, whose life activity was distinguished by greater social independence and autonomy. Small, compact me- 
dieval houses of urban artisans or merchants, representing a combination of industrial and residential premises, were inferior in size, hygiene and decor to the new multi-storey brick buildings. Living in such living quarters, which developed from the spatial image of a Roman villa and urban insula, became the subject of the desire of many rulers.

The strengthening and territorial expansion of the Western European monarchies also required a change in the territorial structure of states. Various forms of medieval buildings, built using local building traditions, ceased to satisfy the unified new way of life of the regional administration. The technology of creating public buildings, cathedrals and residential buildings by local craftsmen began to be considered barbaric and ignorant. The preservation and improvement of the building arts in small workshops where artisans' knowledge of how to build dwellings was based on local experience was considered obsolete.

Teaching methods focused on obtaining general theoretical knowledge in the field of mechanics, physics and mathematics, allowed an increase in the number of architects. With the aim of the emerging trend of unification of buildings built based on the architectural principles of the Roman Empire, Louis XIV in 1671 initiated the creation of L'académie royal d'architecture in Paris. The use of the universal principles of harmony, practicality and rationality, declared in the treatises of the Renaissance, presented in the visual interpretations of his followers, turned out to be politically useful as they ensured the visual homogeneity of the urban environment. The uniform exterior décor helped to smooth out the visual national and social differences that intensified during the era of monarchies (Fig. 2).

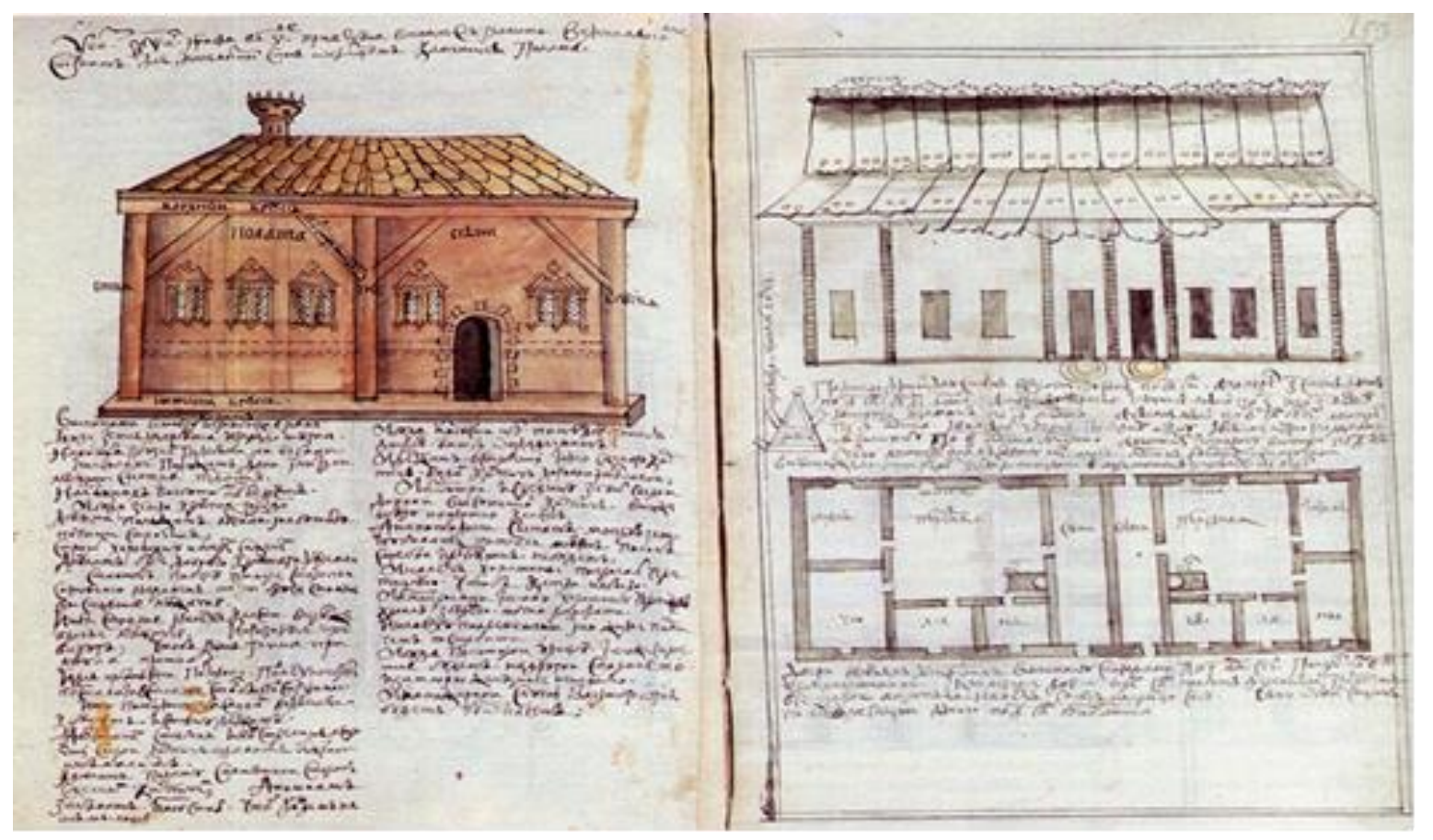

Fig. 2. Typical projects from the end of the 17th century. Single-family house for the city of Tobolsk. Source: (Gulyanitsky, 1994)

Ryc. 2. Typowe projekty z końca XVII wieku. Dom jednorodzinny dla miasta Tobolsk. Źródło: (Gulyanitsky, 1994)

Realizing that interaction with monarchies is impossible based on the feudal structure of the country, Peter the Great carries out a series of social reforms aimed at creating a new spatial model of 
the country. The plan of the new capital, St. Petersburg, fully complied with the principle of matching social parameters to the size of residential premises. Government officials and those close to the tsar had to settle in the " Eminent Houses" - two- or three-story palaces located on large plots (about one hectare). Wealthy people had to settle in "Prosperous Houses" - one-two-story houses with plots ten times smaller. "Minor Houses" (artisans, private traders, etc.) were envisaged, as a rule, one-story mansions with four rooms located around a tiled stove (about $100 \mathrm{~m}^{2}$ in size). Figure 3.To support the policy of approximating the spatial image of the dwelling to the general European models, the Imperial Academy of Arts was created in 1757 year. Soon, a new generation of Russian state architects joined the general direction of European architecture (Brunov, 1951).

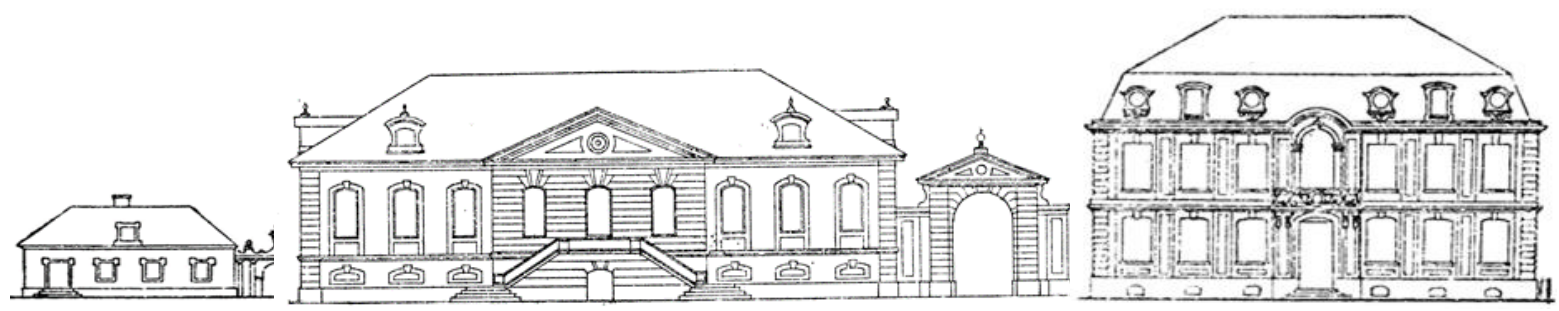

Fig. 3. The "Minor", "Prosperous" and "Eminent" house projects (from left to right) elaborated by the first architect of Saint Petersburg Domenico Trezzini de Suizo. Source: (Brunov, 1951)

Ryc. 3. Projekty domów „Zamożnych” i „Wybitnych” (od lewej do prawej) opracowane przez pierwszego architekta Sankt Petersburga Domenico Trezzini de Suizo. Żródło: (Brunov, 1951)

The borrowed spatial image of the palace (huge rooms, large windows, inevitable attics and basements) did not correspond much to the lifestyle of the urban households, therefore government officials began to build a second dwelling outside the city according to traditional methods. Quarter buildings appeared in the city centres, with multi-storey brick buildings reminiscent of the streets of Venice and Florence, and in the suburbs of the estate in the antique style. Outside of a few large cities, the rest of the population (approximately 97\%) occupied medieval forms of dwellings and preserved traditional rural lifestyle. Despite the relatively high level of heterogeneity of new and traditional dwellings, the differences in the properties of living quarters have increased. The ban on the relocation of serfs to cities reinforced this trend.

The abolition of serfdom was marked by the expansion of the spatial image of the Russian dwelling. In 1700, the urban population of the Russian Empire could be about 400 thousand people, and by 1914 it reached 30.6 million (Federal State Statistics Service, 2006). During this period, the architects acquired new clients. Owners of office buildings, banks, industrial and transport companies began to introduce new requirements for the organization of living quarters. Architectural education moved from the Imperial Academy of Arts to polytechnic institutes. A new generation of architects, whose knowledge was expanded by experience, began to create spaces with a wide variety of geometric characteristics and properties of residential buildings.

The abolition of serfdom in the middle of the 19th century and the permission for peasants to settle in Russian cities contributed to the growth of overcrowding of residence of residential premises and the active spread of unsanitary conditions. In some basements of new buildings, up to 20 people could live. One toilet in a building could have been used by a hundred residents. About $60 \%$ of the population of St. Petersburg lived in houses with a very high population density (more than 20 people per living premises). According to unverified data, there were about 13 thousand one-room apartments in Moscow, in which from 4 to 10 people lived (Kozerenko, 1928). During the First World War, living conditions in Europe deteriorated sharply (Fig. 4). 

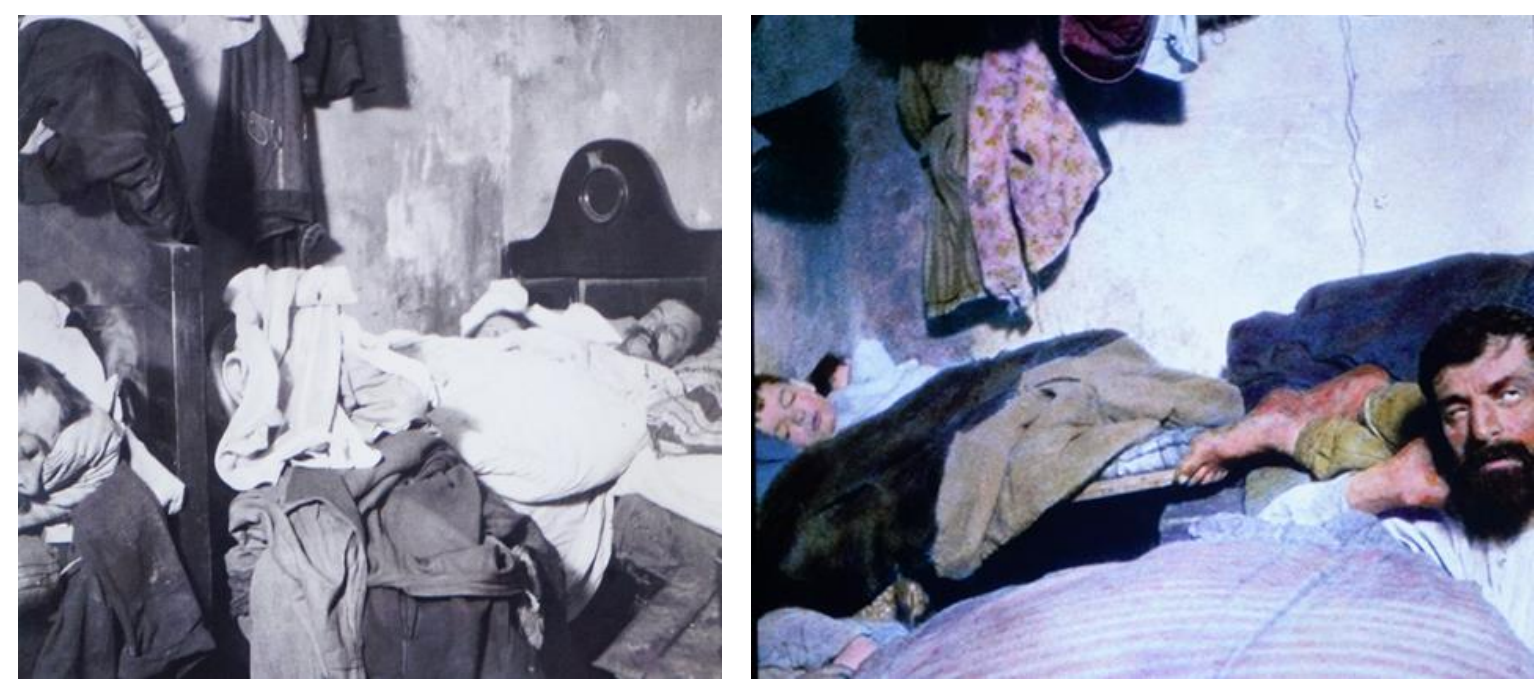

Fig. 4. A typical placing the most Central European population in rooms in the World War I period. Source: (Exhibition "Foto. Buch. Kunst". 28.6.2019-22.9.2019, Albertina, Vienna)

Ryc. 4. Typowe zamieszczenie, środkowoeuropejskiej ludności w okresie I wojny światowej. Źródło: (Wystawa „Foto. Buch. Kunst". 28.6.2019-22.9.2019, Albertina, Wiedeń)

City administrations in Western Europe faced the problem of overpopulation earlier and began to look for solutions through organizational change. In addition to the desire of liberal and conservative politicians to find financial and technological ways to solve the housing problem, the leaders of the communist movement managed to convince part of the population of the need for social transformations - "the demolition of private property will solve the housing problem" (Marks \& Engels, 1870). This meant that no one had the right to use land and buildings as a means of income. All residential premises in the country were to be owned by the state, which was supposed to provide control over the pace of construction and its distribution. Food, clothing, housing became a way of government reward. A new concept of residential versatile living space emerged, in which the room, as the main resting place, was viewed exclusively as a bedroom. Kitchens, bathrooms and toilets must be accessible to the public. Industrial educational or amateur activities were to be taken out of the dwelling.

\section{PERIODIC CHANGES IN THE SPATIAL IMAGE OF THE SOVIET MASS STANDARD PREFABRICATED DWELLING}

The adoption of the law on the complete nationalization of the land made it possible at the end of 1917 to transfer all the property of the country into the possession of the territorial authorities. Although the civil war prevented the implementation of social reforms, the country's leadership managed to formulate the main principle of housing policy - "to strive with all its might to improve the living conditions of the working masses"(Rubanenko, 1976). As a result of the execution of the decree on the confiscation of private city apartments into state ownership, the country's housing stock was redistributed following the accepted standard of residence. Most of the city apartments were occupied by several households. State ownership of urban dwellings also made it possible to more efficiently regulate the process of converting dwellings into non-dwelling ones. The need to provide the entire population of the country with full employment led to the active use of residential premises for state-owned companies, which further worsened housing conditions in cities.

The dream of most peasants to live in city apartments with a bathroom and hot water came true almost instantly. The living area per person in housing at that time in Russia was approximately $4 \mathrm{~m}^{2}$. The form of close living has caused a huge need for the acquisition of a separate apartment. The state decided to solve the problem with the help of small apartments (1-2 rooms with a maxi- 
mum total area of 30-50 $\mathrm{m}^{2}$ ). The first attempts to implement houses with small living quarters in apartment buildings with collective kitchens and laundries turned out to be unsuitable, which led to their subsequent use as offices.

The new spatial image of the city-dwelling, proposed at the Paris exhibition of 1922 by Le Corbusier, seemed to meet all the requirements of state-building. Giant skyscrapers, located at a considerable distance from each other, resembled manor buildings, which visually demonstrated the merger of city and village. His proposed plan for the reconstruction of Moscow according to this spatial image was not accepted due to the excessive costs of demolishing historic buildings (Fig. 5).

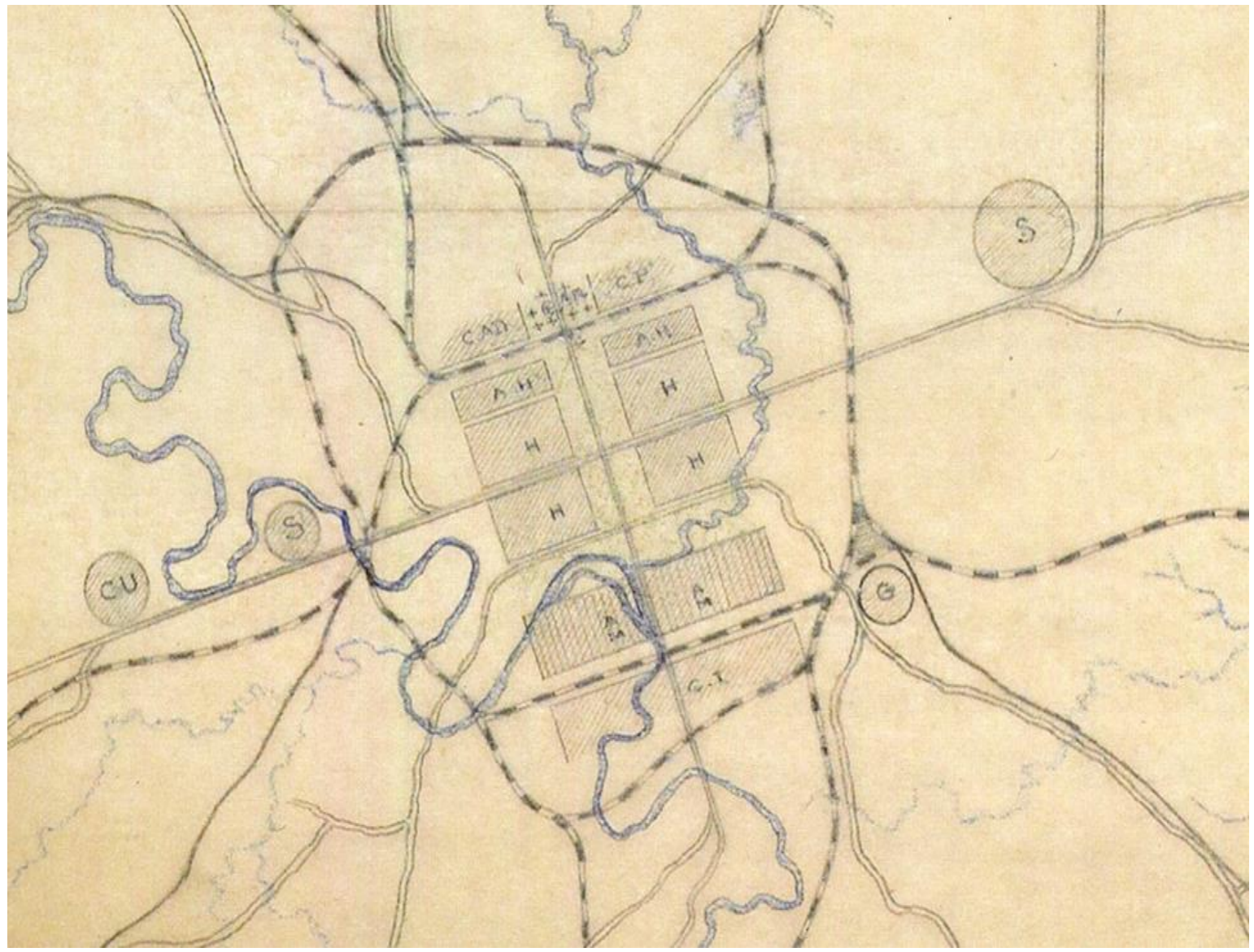

Fig. 5. Moscow city plan prepared by Le Corbusier in 1930. Source: (Jean-Louis Cohen, 2012)

Ryc. 5. Plan miasta Moskwy przygotowany przez Le Corbusiera w 1930. Źródło: (Jean-Louis Cohen, 2012)

The slow pace of economic development forced the soviet government to allow private entrepreneurship and return to market trading. Fearing the emergence of a new wealthy class of customers, which could be led to the elimination of the idea of universal living space, for control over the design process have created the Union of Soviet Architects and the Academy of Architecture in the 1934 year. From that moment on, the spatial development of the country began to again submit to political views. A small community of architects began to look for standard designs that could be reused throughout the country. After World War II, the destroyed buildings of Eastern Europe needed to be rebuilt. The sharp increase in the post-war urban population forced the state to increase the pace of construction. A small number of large state-owned construction companies focused on the creation of high-rise buildings in large cities were mainly aimed at solving ideological tasks and were unable to increase the volume of construction. 
The results of the 1959 census showed that the provision of the population with housing has not improved. It turned out that the houses built according to the designs of the Academy of Architecture of the USSR are expensive. This was the beginning of sharp criticism of the work of Soviet architects and accusations of "wastefulness and excessive enthusiasm" for architectural decor. The government decided to adopt the post-war French experience in the conveyor belt construction of multi-storey buildings. Economic calculations have shown that, provided that such house-building factories are built in the main regions of the country, focused on the construction of one standard type of house by 20 years would be sufficient to achieve correspondence between the number of apartments and the number of households in the country. The right to develop the project of such a house was given to the central design institutes. After an economic analysis of various types of dwellings, a five-storey building with ten small-area apartments equipped with a compact kitchen and a sanitary unit was selected. This type of house, developed during the restoration of European dwellings after the First World War, also became the basis for the spatial image of Eastern European dwellings in the 20th century.

The first compact apartments in prefabricated dwelling houses of mass production, which had been appeared in the USSR in the early 60s, did not have enough space to accommodate household increasing items. In 1963-1970, the government was forced to increase the size of the living space of standard apartments. The low productivity of house-building factories and the high cost of delivering heavy construction products turned out to be costly. Demographic growth, which outstripped the pace of construction, began to affect the birth rate. Hygiene studies have confirmed the negative effects (respiratory, circulatory and digestive diseases) caused by living in small, densely populated apartments. It was also concluded that the influence of the living environment does not significantly affect the birth of the first child, however, the likelihood of having a second and third child largely depends on the physical living conditions and affects the quality of family life (Khachatryants, 1968). Numerous studies of the 80 s also demonstrated that the ideas about the quality of dwellings among architects and the population were different (Kruusvall, Heidemets, 1986). Even though a typical apartment was distinguished by good operational qualities (they had control of heat, solar lighting and ventilation) and had a minimum set of necessary equipment (a stove for cooking, and the necessary plumbing equipment), most of the population had complained about the inadequate distribution of space in rooms, the arrangement of doors and windows and geometric parameters of premises that do not have been guaranteeing the comfort of their living.

Population dissatisfaction with apartment size began to decrease as the supply of apartments increased and family size decreased but did not completely disappear, since the range of requirements expanded significantly as a result of an increase in the diversity of forms of life. For example, single-parent families (living with one of the parents) were willing to sacrifice part of their bedroom in order to get an additional bathroom or change the entrance to the apartments. It was found that the requirements for the geometric parameters of rooms are directly dependent on the life cycle and health status of family members (Kiyanenko, 2005). The nature of the use of residential premises also had to be changed under the development of urban infrastructure, the climatic region and family traditions (Kartashova, 1985).

Despite technical limitations, the administrations of many Soviet cities began to introduce an automated system for managing the distribution of housing, which made it possible to somewhat regulate differences in living conditions. The average living area per inhabitant in the country has gradually increased and reached about $15.2 \mathrm{~m}^{2}$ in 1985, which allowed for a wider geometric variety of apartments. However, this required the re-equipment of hundreds of house-building factories, which turned out to be impossible due to the costs associated with the development of engineering infrastructure. Only $12 \%$ of suburban residential buildings had hot water and could physically approximate a modern city apartment. That was a cause of increased the outflow of the population to cities and an increase in the number of families waiting for a larger apartment. For example, in L'viv, almost a quarter of families were waiting for resettlement to the new apartment (Derzhkomstat URSR, 1991).

The development of housing based on a universal image of a city apartment with a narrow range of parameters under the conditions of a total state form of ownership could not provide the necessary 
variety of living conditions based on the expanding range of requirements caused by dynamic changes in the lifestyle of the population (Durmanov, 1992). To respond more dynamically to changing requirements for the geometric characteristics of residential premises, the state should have had a more developed level of information technology development.

The desire to transfer all living quarters of Russia to the ownership of citizens meant a failure of the state spatial policy. That did not mean an instant removal of geometric restrictions in housing legislation, nevertheless, thanks to the inclusion of private investors in the reconstruction process of dwellings, it almost instantly had expanded the diversity of the geometric parameters of the spatial image of Russian apartments. Apartments in city centres began to be actively bought and reconstructed. The housing stock in large cities has been enriched with skyscrapers and low-rise cottages. Many apartments were rented out unfinished for the owners to finish building them according to their requirements. The variety of apartments has increased explosively (Fig. 6).
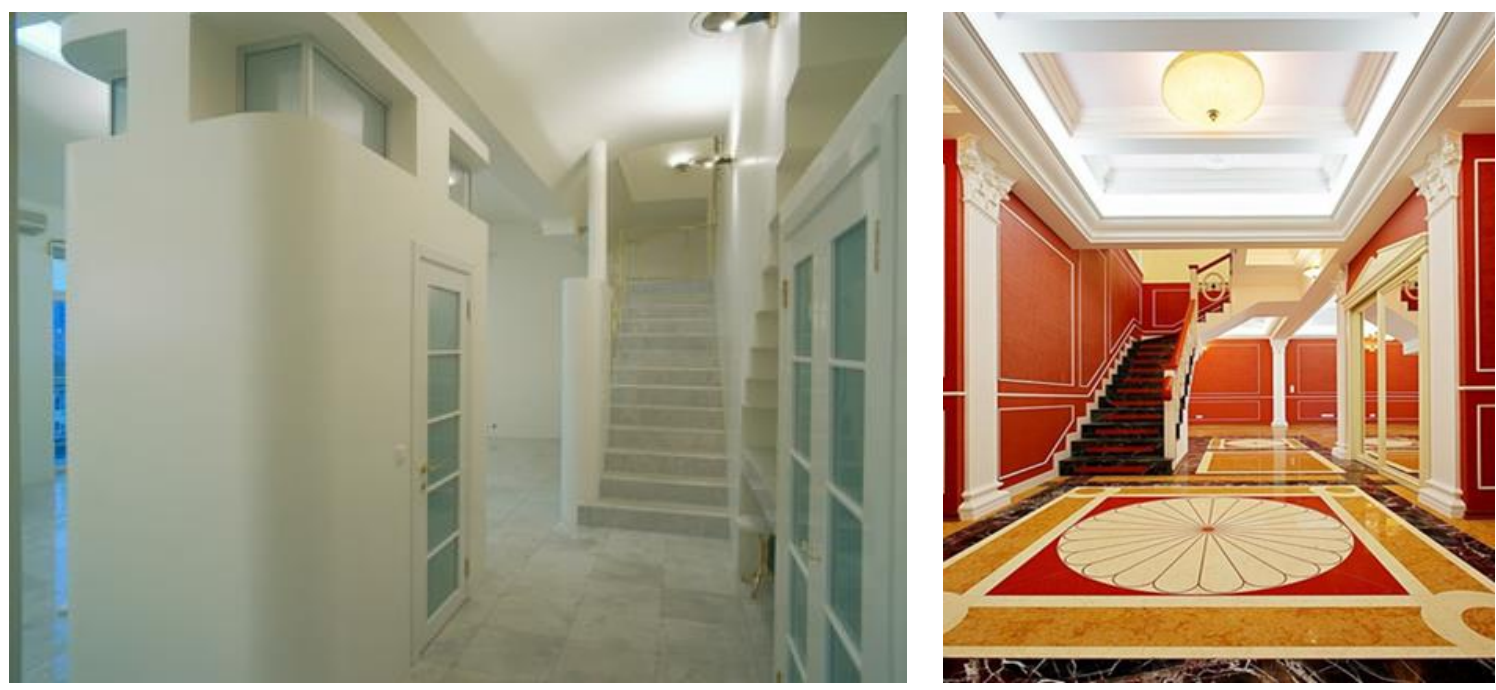

Fig. 6. Results of reconstruction the former "communalka” in prestige rented apartment for „Prosperous" in the central part of Moscow. Source: (author collection)

Ryc. 6. Efekty przebudowy dawnej „communalki” w prestiżowym wynajmowanym mieszkaniu dla „Zamożnych” w centralnej części Moskwy. Źródło: (ze zbiorów autora)

The housing needs of wealthy households were met very quickly. Sales to the secondary home market declined as buying a new apartment meant a complete or partial renovation of the dwelling. Construction companies had to again reduce the parameters of the apartments to the minimum and rent them in a more finished. Thirty years after privatization, the spatial image of the new Russian city apartment returned to its traditional shape, size and planning organization (Fig. 7).

A hundred years after the Great October Revolution, the total living area of Russia has grown more than 20 times and reached 2.709 million $\mathrm{m}^{2}$, while the population increased only 7 times $(109.3$ thousand people). The share of private premises in the city housing stock during the years of privatization increased from $20 \%$ to more than $90 \%$. Private housing began to be used not only for living but also for rent. The share of houses built with private capital began to gradually increase and amounted to about $43 \%$, but, despite the participation of the population's resources in the technical modernization of construction companies, the change in the structure of the country's residential premises is proceeding slowly. 

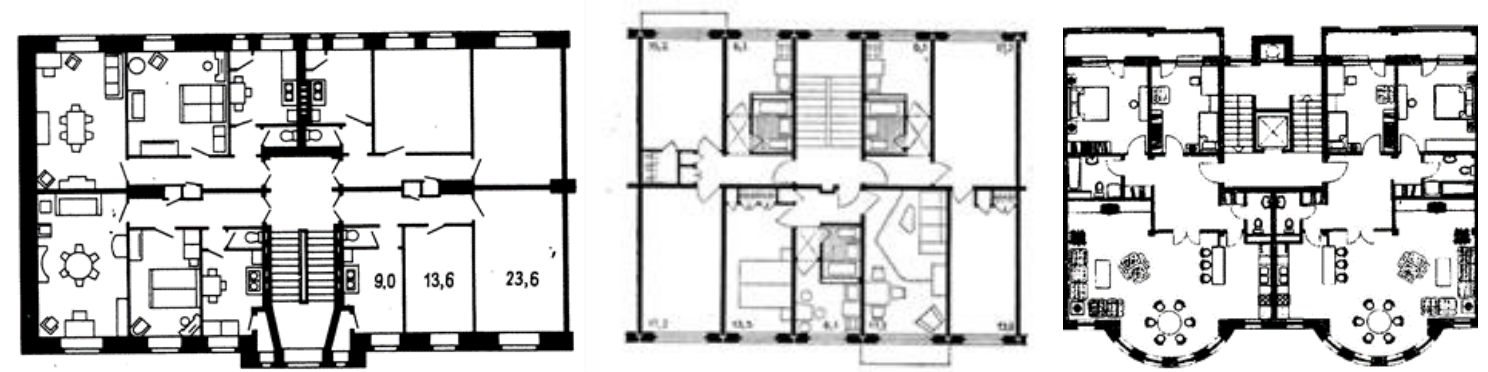

Fig. 7. Plan of a typical house in Moscow, 1925 (left); standardized with prefabricated panels; 1963 (center), modern housing in Nizhny Novgorod, 2002 (right).

Ryc. 7. Plan typowego domu w Moskwie, 1925 (po lewej); znormalizowany z prefabrykowanymi panelami; 1963 (w środku), nowoczesne mieszkania w Niżnym Nowogrodzie, 2002 (po prawej).

\section{RESULTS}

The geometrical characteristics of the country's dwelling are in the process of constant change. Concepts for improving the quality of living quarters arise in society as a result of the awareness of inconsistencies arising in the structure of the spatial image of an apartment. When a household realizes that its desired and real living conditions cease to meet the high-quality performance of the implemented and planned life processes, it tries to direct efforts to transform it. If such transformation is impossible due to economic, social or cultural constraints, they forced migration. In the face of the growing dissatisfaction of the population with their living conditions, the society will have again to transform the spatial image of housing based on local experience of construction by the stimulating development of investigation of living premises of state this time.

There are several reasons for the sustainability of the reproduction of the spatial image of a Russian city apartment over the past century. First, a significant part of the population (over 95\%) lives in houses built during the Soviet era. Secondly, architects, most of whom see the essence of the profession in the representation of global stylistic trends in the external appearance of the building, pay little attention to local changes associated with a lifestyle change. Thirdly, construction companies, in the face of increased demand for housing, turned out to be uninterested in finding a new geometry of dwellings associated with the development of design technologies, arguing that the population does not need to change the geometric quality of an apartment.

Also, the pandemic has shown that it was impossible to maintain social distance in apartments with high density, one sanitary facility and the impossibility of installing the necessary medical equipment. In the countries with a high level of computer education of the population and a developed system of remote medical control revealed an elementary shortage of premises in dwellings to leave the sick at home. The forced construction of temporary hospitals did not solve the problem of spreading epidemics in cities. The latest mutations of SOVID-19 show that the invention of a vaccine and the search for drugs is not the only way to save lives, as it became known after the Black Death in Europe, which might be updating the architect profession again.

\section{CONCLUSIONS}

1. Regular statistical observations of the development of the geometric characteristics of living premises, begun in the second half of the last century, demonstrate a gradual increase in the average area, the number of rooms and engineering equipment in all modern developed countries. The desire to increase the size of the dwelling reflects the general trend of social development associated with the need to increase the spatial sovereignty of private households, expressed in the desire for greater physical isolation, independency and autonomy from the environment. 
2. Significant transformations of the spatial image of a city apartment are observed during periods of significant social transformations. An increase in geometric diversity can be traced during periods of expansion of practical experience in construction associated with the search for more effective local ways to improve the quality of premises. Such expansion does not always lead to an improvement in the quality of the environment. A narrowing of the range of parameters in the spatial image of a dwelling is observed with the expansion of external information impact. The desire to bring the geometric characteristics of a particular apartment closer to its general spatial image can be traced in periods of reassessment of social values. Usually, such a change is due to a decrease in the quality of local housing in comparison with the global one and is associated with the confidence of borrowing the historical or social experience of a more developed culture

3. Informational "external" impact based on the borrowing of historical or territorial experience of construction and "internal" associated with the desire to implement construction in a specific formbuilding production environment occur simultaneously. Strengthening this or that form of influence is usually a consequence of the awareness of the negative consequences caused by the adopted direction. The development of the spatial knowledge of society is influenced by the homeostatic balance between specific experiential and overall global concepts. Although over the past century a global commercialized real estate market has been created, which has provided the development of housing design along the path of stylistic dynamics, the search for new forms of design that goes beyond the aestheticized information impact seems inevitable.

\section{WPŁYW POLITYKI PAŃSTWA NA ROZWÓJ GEOMETRII POMIESZCZEŃ NA PRZYKŁADZIE EWOLUCJI ROSYJSKIEGO MIESZKANIA}

\section{WPROWADZENIE}

Wiadomo, że przez znaczną część naszego życia musimy dostosować się do zmiennego środowiska zewnętrznego. Zmiana właściwości i geometrii środowiska wpływa na nasze samopoczucie i zdrowie nie mniej niż procesy zachodzące w nas. Przypuszczalnie świadomy stosunek do względnie stabilnej geometrii niektórych naturalnych pomieszczeń (jaskiń, grot, koron drzew itp.) pozwolił ludziom nauczyć się, jak je sztucznie odtworzyć. Budynki i budowle nie zawsze służyły przez długi czas. Konieczność poprawy warunków życia zmuszała do budowy nowych lub przekształcenia starych pomieszczeń, kiedy z powodu utraty przydatności musiały zostać zniszczone lub porzucone. Obserwacja dynamiki cech sztucznych pomieszczeń współczesnych państw pozwala nam stwierdzić, że tempo i formy ich geometrycznej transformacji przyspieszają i rozszerzają się.

W drugiej połowie ubiegłego wieku nastąpiły znaczące zmiany w polityce mieszkaniowej wielu krajów, co wpłynęło na zmianę struktury własności przedsiębiorstw budowlanych oraz technologię projektowania architektonicznego. Późniejsze doświadczenia w funkcjonowaniu zbudowanych mieszkań ujawniły kilka wad związanych $z$ ich konsumpcją (pogorszenie stanu zdrowia ludności związane z przeludnieniem komnat; konieczność ciągłej zmiany miejsc zamieszkania spowodowanej dynamiką cyklu życia; rosnąca liczba pustych i opuszczonych budynków itp.). Różnorodność i wyjątkowość geometrycznych form stworzonego środowiska życia pobudziła rozwój ich badań we wszystkich krajach (Alexander C., Altman I., Baum A., Bechtel R., Cambell D., Davis W., Gale N., Herzog T., Kaplan R., Kaplan S., Lang J., Maslow A., Mintz N., Nasar J., Parsons R., Russell J., Steinitz C., Urlich R., Worchel S., Zejsel J. i inne). Na początku lat 80., niektórzy psychologowie i architekci połączyli siły w prowadzeniu badań na dużą skalę miejskich pomieszczeń mieszkalnych, tworząc grupę naukowców Moskwy i Tallina (Kartashova - Heidmets), co umożliwiło sformułowanie głównych podejść do określania ich cech. Wydarzenia historyczne pod koniec ubiegłego 
i na początku nowego wieku nie pozwoliły na przedstawienie wyników tych badań w zewnętrznych publikacjach naukowych, chociaż wiele wniosków znalazło odzwierciedlenie w kolejnych rosyjskojęzycznych rozprawach (Albanov S., Barmaszyna L., Zabruskowa M., Koloskov V., Kruusvall J., Menshykova E., Molczanov V., Niit T., Ovsiannikov V., Ovsiannikova N., Orlov P., Smotrikowskij V., Volov V., и oraz inni). Przeprowadzone badania umożliwiły również ustalenie pojęcia pomieszczeń mieszkalnych jako przedmiotu badań interdyscyplinarnych oraz jego przestrzennego lub geometrycznego obrazu czy wizerunku jako genetycznej podstawy jego reprodukcji, która prezentowała się na wszystkich etapach produkcji i konsumpcji mieszkań.

Pojęcie lokale mieszkalne lub pomieszczenia mieszkalne stały się aktywnie wykorzystywane w badaniach socjologicznych i statystycznych po II wojnie światowej. Zwykle definiuje się jako strukturalnie oddzielone wewnętrzne części budynków, które są używane lub przeznaczone do zamieszkania przez ludzi. Rozszerzona interpretacja tej koncepcji obejmuje szeroki zakres geometrycznych kształtów pomieszczeń - od pokoi do innych pojemności związanych z nimi, które tworzą jednolity produkt konsumpcji. Różnorodność pomieszczeń pozwala na ich klasyfikację według stopnia izolacji od środowiska zewnętrznego, czasu użytkowania, mobilności itp. W przeciwieństwie do pojęcia przestrzeni życiowej, która jest opisana jako szeroki zakres subiektywnych i obiektywnych zjawisk związanych z miejscem zamieszkania ludzi, pomieszczenia mieszkalne odzwierciedlają idee dotyczące jego materialnych właściwości trójwymiarowych i cech geometrycznych.

Przed pojawieniem się pierwszych sztucznie stworzonych pomieszczeń, ich ewolucyjne formy i kształty były reprezentowane przez szeroką gamę otwartych i półotwartych konstrukcji w miejscach tymczasowego pobytu. Pierwsze sztuczne efemeryczne mieszkania wykonane z kości mamuta pojawiły się na terenie współczesnej Ukrainy, około 20 tysięcy lat temu (Pidoplichko, 1969). Ocalałe pozostałości starożytnych osiedli miejskich, których początki powstały we wczesnych despotycznych państwach, świadczą o ogromnej różnorodności materiałów budowlanych i technologii, z których zostały zbudowane. Nawet w granicach jednego obszaru kulturowego, znaczne różnice występują w wielkości pomieszczeń i ich organizacji przestrzennej (Baker, 2014). Pomimo ogromnej różnorodności mieszkań, porównywalnych z wyjątkowością wszystkich żyjących gospodarstw domowych, w każdej społeczności społeczno-terytorialnej można znaleźć dość stabilne geometryczne cechy pomieszczeń, które utrzymują się na dość długim etapie rozwoju kulturowego, który w tym badaniu nazywany jest jego przestrzennym obrazem.

Główne cechy przestrzennego obrazu pomieszczeń mieszkalnych zwykle przedstawia się przez jego powierzchnie, liczbę pokoi, układ oraz cechy sprzętu i mebli. Ujawnianie ich właściwości, reprezentowane przez jego zmienność i zdolność do odzwierciedlania kierunku zmian w życiu społeczności, jest jednym z zadań nauki architektonicznej. Praktyczna wartość takich badań jest zwykle związana z poprawą procesu projektowania architektonicznego.

Przestrzenny obraz pomieszczeń mieszkalnych, reprezentowanych przez produkty działalności materialnej i duchowej, jest idealnym zjawiskiem, które łączy w sobie obiektywny i subiektywny świat dzięki jedności metrycznej i topologicznej natury przestrzeni. W projektowaniu architektonicznym, przestrzenny obraz pomieszczeń, jako rodzaj wstępnej idei, która orientowana na udoskonalenie miejsca zamieszkania, aby osiągnąć pożądany rezultat, przechodzi przez kilka etapów dyskursu, przy użyciu pewnych środków zewnętrznych i zasobów energetycznych. Proces ten kończy się stworzeniem obrazu konkretnej konstrukcji, która w procesie subiektywnej konsumpcji stopniowo rozwija nowe podejście do niego za pomocą abstrakcyjnych pojęć. Proces konkretyzacji i abstrakcji to dwa najważniejsze, ale nie jedyne procesy związane z osiągnięciem żądanej transformacji pierwotnego pomieszczenia. Świadome poruszanie się w idealizowanej przestrzeni wyobraźni od ogólnych geometrycznych do specyficznie sformalizowanych cech i odwrotny umysłowy proces związany ze stopniową eliminacją nieważnych i nieznaczących właściwości pomieszczenia do podkreślenia najbardziej podstawowych jego cech, towarzyszą również procesowi projektowania na wszystkich jego etapach.

W przedstawionym badaniu główną uwagę zwraca się na wpływ indywidualnego i zbiorowego doświadczenia na transformację przestrzennego obrazu mieszkania. Doświadczenie zdobyte przez określoną grupę społeczno-demograficzną związaną z zamieszkaniem w podobnych warun- 
kach z identycznymi geometrycznymi parametrami pomieszczeń może się różnić ze względu na różnice $w$ trybie życia. Jednocześnie wpływ wyników produkcji budowlanej realizowanej $w$ jednym środowisku technologicznym może mieć również inne skutki na odległym terenie. Oba procesy związane $z$ asymilacją do budynku jak i jego inspirowaną pod wpływem "zewnętrznego" i "wewnętrznego" doświadczenia, mogą zmienić kierunek i metodę fachowego architektonicznego projektowania mieszkań.

Celem artykułu jest twierdzenie, że cykliczny charakter zmian jakościowych odkryty w ewolucji geometrii mieszkania i determinujące jego cechy konsumenckie, zależy od okresowej zmiany parametrów w przestrzennym obrazie pomieszczeń mieszkalnych państwa, które odzwierciedlają stosunek populacji do zbiorowego i osobistego doświadczenia w jego używaniu i produkcji. Wzajemny i jednoczesny wpływ przestrzennych zjawisk powstających na terenie wspólnoty pod wpływem globalnych zmian i lokalnego doświadczenia praktycznego w środowisku utworzonym w szczególnych warunkach jest trudny do uświadomienia, metodami analizy statystycznej czy socjologicznej, które dopiero niedawno stały się celem okresowych badań mieszkań w Rosji. Jednak założenia dotyczące istnienia $\mathrm{w}$ procesie projektowania architektonicznego pewnej dynamiki przestrzennych zmian, które determinują potrzebę w geometrycznej transformacji pomieszczeń mogą poprawić jakość przyszłych mieszkań.

\section{CYKLICZNA DYNAMIKA CECH GEOMETRYCZNYCH W OBRAZIE PRZESTRZENNYM POMIESZCZEŃ MIESZKALNYCH W ROSYJSKIM BUDOWNICTWIE}

Niekorzystny klimat dla rozwoju gospodarki wiejskiej w Europie Wschodniej nie przyczynił się do rozwoju struktury społecznej społeczności, co znalazło odzwierciedlenie w tworzeniu prostego i dość uniwersalnego wizerunku tradycyjnego rosyjskiego mieszkania. Technologia produkcji dużych desek i kłód, opracowana przed rozpoczęciem działalności rolniczej (Lehmann, 1998), umożliwiła wznoszenie prostokątnych kształtów, małych powierzchni, jednopokojowych półpoziomowych budynków pokrytych grubą warstwą ziemi na drewnianych belkach (Terpilovsky, 1994). Pomieszczenie było ogrzewane paleniskiem umieszczonym w glinianych lub kamiennych piecach, z którego dym zwykle uciekał przez małe okna w ścianie lub przez dziurę w dachu, która była zamknięta w nocy (Rappoport, 1993). Zazwyczaj piece te zajmowały od 3 do $10 \%$ powierzchni pomieszczenia. W IX wieku podobne mieszkania, które służyły jako schronienie przed zimowym mrozem dla dużych gospodarstw rolniczych, rozprzestrzeniły się po całej Europie Wschodniej i istniały w niektórych wiejskich osadach do początku ubiegłego wieku. Oprócz cech rozmieszczenia i wielkości pieców zaobserwowano różnice regionalne w poziomie rozmieszczenia podłogi pomieszczenia, sposobie łączenia kłód oraz cechach konstrukcji dachu (Blomkwist, 1956).

Różnorodność mieszkań wzrosła na tym terytorium w okresie rozprzestrzeniania monoteistycznych przekonań religijnych. Byzantium, wypędzone z Bliskiego Wschodu przez arabski kalifat, stanęło w obliczu groźby ataku również ze strony nowych państw, które pojawiły się w Europie Zachodniej. W wyniku swojego poparcia politycznego znaczna część księstw zamieszkujących terytorium Równiny Wschodnioeuropejskiej, zjednoczyła się w dużą jednostkę społeczną o nazwie "Rusi Kijowską", której zasoby terytorialne i społeczne można porównać z Królestwem Franków. Bliski związek informacyjny między Kijowem a Konstantynopolem wpłynął na lokalną produkcję mieszkań. Aktywne wprowadzenie bizantyjskiej technologii konstrukcji kamiennej przyczyniło się do powstania budynków, których ściany zostały zbudowane z cegieł związanych z zaprawą cementu. Zastosowanie nowych technologii okazało się trudne i czasochłonne. Okazało się niemożliwe do wzniesienia takich budynków w zimie ze względu na zamrożenie zaprawy cementowej. Aby pokoje w kamiennym domu pozostały ciepłe w nocy, ich ściany musiały mieć grubsze ponad metr. Kamienne budynki w warunkach półtora metra zamarzania gleby wymagały również dogłębnego rozmieszczenia fundamentów. Wprowadzenie kamiennej technologii budowlanej w budowie mieszkań zwiększyło jej energochłonność, powodując rozbudowę obszaru logistycznego związanego z zaangażowaniem zasobów ludzkich podwładnych księstw. To znacznie osłabiło rząd centralny i mogło stać się jedną z przyczyn upadku państwa kijowskiego.

Nie jest możliwe uzasadnienie stopnia wpływu tej polityki architektonicznej na zdolność do prze- 
trwania państw tego okresu, w oparciu o ograniczoną ilość dostępnych informacji historycznych. Odporność na pożary konstrukcji kamiennych pozwalała na bardziej zwarte umieszczenie budynków mieszkalnych. W przeciwieństwie do zachodnioeuropejskich średniowiecznych mieszkań miejskich, w których kamień był szeroko stosowany, w Europie Wschodniej, pomieszczenia utworzone w ceglanych budynkach były przeznaczone głównie dla elity i stały się oznaką statusu społecznego. W tym okresie wygląd miejskich budynków mieszkalnych stopniowo zaczął się różnić od tradycyjnej wsi.

Miejskie budynki mieszkalne Rusi Kijowskiej nie przetrwały, ale dzięki starożytnym kronikom zakłada się, że różnorodność geometrycznych cech budynków została rozszerzona ze względu na połączenie zapożyczonej technologii kamiennej i tradycyjnej konstrukcji drewnianej ramy, tworząc nowy obraz przestrzenny, który pozwala na zwiększenie liczby pięter i liczby pomieszczeń. Jednak skala budownictwa miejskiego pozostała nieznaczna, co miało niewielki wpływ na styl życia ludności zajmującej się głównie rolnictwem.

Ocieplenie klimatu w średniowieczu spowodowało ekspansję pustyni Gobi. Rozproszone koczownicze plemiona, które zamieszkiwały mongolski płaskowyż, znalazły się w kryzysie żywnościowym, który zmusił ich do poszukiwania nowych źródeł utrzymania, próbując podbić duże miasta, aby przejąć ich zasoby materialne. Po zdobyciu części Europy Wschodniej przez wojska mongolskie w 1240 r. znaczna liczba państw słowiańskich znalazła się pod presją polityczną i gospodarczą. Budowa na tym terenie praktycznie ustała w tym okresie. Chęć oparcia się utracie niepodległości w niektórych księstwach miała miejsce w przemianach społecznych (powstanie republik Nowogrodzkiej i Pskowa), które doprowadziły do intensyfikacji działalności rzemieślniczej i budowlanej. $\mathrm{Na}$ terenie feudalnych miast słowiańskich pojawiła się nowa forma pomieszczeń mieszkalnych zwana "Kremlem" (defensywny kompleks budynków z pomieszczeniami administracyjnymi, religijnymi i mieszkaniami). W późnym średniowieczu wysoki stopień autonomii przestrzennej i izolacja tego wielofunkcyjnego budynku pozwoliły ludności miejskiej utrzymać swoja suwerenność. Po stuleciu budowy małych pomieszczeń, spowodowanych spadkiem ilości wyrobów budowlanych i wzrostem gęstości życia, nowy rodzaj przestrzennego obrazu mieszkania określił kierunek jego dalszego rozwoju.

Potrzeba wzmocnienia obrony państw pobudziła powstawanie różnych form zinstytucjonalizowanych mieszkań. Ważnym wydarzeniem historycznym było przeniesienie rezydencji prawosławnych metropolitów z klasztoru na Kreml Moskiewski. Pozwoliło to wielkiemu księciu Dmitrijowi Dońskiemu w 1325 roku, pod hasłem zachowania prawosławia, przewodzić koalicji anty hordy i rozszerzać pierścień ufortyfikowanych klasztorów wokół stolicy, tworząc z niej nowe polityczne centrum kraju. Wysoka aktywność społeczna wewnątrz Kremla wymagała zwiększenia ich wymiarów. Wykorzystanie technologii łuków wspartych na gęstej siatce kolumn, przyjęte z bizantyjskiego doświadczenia $\mathrm{w}$ budowie sklepień krzyżowych, okazało się pracochłonne i nieskuteczne przy potrzebie zwiększenia powierzchni pomieszczenia we wszystkich kierunkach. Tymczasem w Europie Zachodniej, ze względu na potrzebę rozwoju wieżowców, obraz przestrzenny rzymskiej bazyliki został poprawiony za pomocą technologii wykorzystania kamiennych konstrukcji ramowych. Car Iwan III (1440-1505), zdając sobie sprawę z znaczenia stosowania nowych technologii, zaprosił znanych europejskich inżynierów do wzmocnienia Kremla Moskiewskiego. Nowy rodzaj opalanej cegły, Iżejszy i o dokładniejszym kształcie geometrycznym, zwiększył szybkość budowy i obniżył koszty energii. Obraz przestrzenny pomieszczeń mieszkalnych elitarnego mieszkania miejskiego stał się bardziej zróżnicowany (Rys. 1).

Wzmocnienie scentralizowanej władzy państwa moskiewskiego poprzez zmianę społecznoprzestrzennej organizacji miast umożliwiło rozszerzenie jego terytorium, którego wielkość przekroczyła obszar zajmowany przez niepodległe państwa Europy Zachodniej. Zagospodarowaniu nowych terenów towarzyszyła ekspansja doświadczeń budowlanych i pojawienie się specjalnych form mieszkań dla rzemieślników i kupców. Przez kilka dziesięcioleci osiedla położone na opuszczonych brzegach północnych mórz i Syberii powstałe nieruchomości nabywały nowe formy, układy kompozycyjne i rozmiary.

Jednocześnie w Europie Zachodniej konkurencja polityczna doprowadziła do znaczących przemian społecznych i technicznych. Działalność handlowa i produkcyjna, wzmocniona działalnością insty- 
tucji finansowych, przyczyniła się do powstania powszechnego mieszkania miejskiego. Odkrycie uniwersalnych praw w przyrodzie stworzyło zaufanie do jednego ewolucyjnego kierunku rozwoju społecznego. Istniała pewność, że budowa "florenckiego pałacu bankiera" z rozwiniętą strukturą planowania pomieszczeń mieszkalnych jest najbardziej odpowiednią formą zamieszkania dla nowej elity finansowej, której działalność życiowa wyróżniała się większą niezależnością społeczną i autonomią. Małe, kompaktowe średniowieczne domy miejskich rzemieślników lub kupców, reprezentujące połączenie pomieszczeń przemysłowych i mieszkalnych, były gorsze pod względem wielkości, higieny i wystroju od nowych udekorowanych tynkiem i kamienna rzeźbą ceglanych ścian wielopiętrowych budynków. Życie w takich mieszkaniach, które rozwinęły się z przestrzennego wizerunku miejskiej rzymskiej willi $i$ insuli, stało się przedmiotem pragnienia wielu nowych władców.

Wzmocnienie i ekspansja terytorialna monarchii zachodnioeuropejskich wymagała również zmiany struktury terytorialnej państw. Różne formy średniowiecznych budynków, zbudowane przy użyciu lokalnych tradycji budowlanych, przestały zaspokajać jednolity nowy sposób życia administracji regionalnej. Technologia tworzenia budynków użyteczności publicznej, katedr i budynków mieszkalnych przez miejscowych rzemieślników zaczęła być uważana za barbarzyńską i nieświadomą. Zachowanie i doskonalenie sztuki budowlanej w małych warsztatach, w których wiedza rzemieślników na temat budowy mieszkań opierała się na lokalnym doświadczeniu, została uznana za przestarzałą.

Metody nauczania skoncentrowane na uzyskaniu ogólnej wiedzy teoretycznej w dziedzinie mechaniki, fizyki i matematyki pozwoliły na zwiększenie liczby architektów. W celu pojawienia się tendencji ujednolicenia budynków zbudowanych w oparciu o zasady architektoniczne Cesarstwa Rzymskiego, Ludwik XIV w 1671 roku zainicjował utworzenie L'académie royal d'architecture w Paryżu. Zastosowanie uniwersalnych zasad harmonii, praktyczności i racjonalności, zadeklarowanych $w$ traktatach renesansu, przedstawionych w wizualnych interpretacjach jego zwolenników, okazało się politycznie użyteczne, ponieważ zapewniły one wizualną jednorodność środowiska miejskiego. Jednolity wystrój zewnętrzny pomógł wygładzić wizualne różnice narodowe i społeczne, które nasiliły się w epoce monarchii (Rys. 2).

Zdając sobie sprawę, że interakcja z monarchiami jest niemożliwa w oparciu o feudalną strukturę kraju, Piotr Wielki przeprowadza szereg reform społecznych mających na celu stworzenie nowego modelu przestrzennego kraju. Plan nowej stolicy, Petersburga, w pełni zgodne z zasadą dopasowania parametrów społecznych do wielkości lokali mieszkalnych. Urzędnicy państwowi i bliscy cara musieli osiedlić się w "Budynkach Wybitnych" - dwu- lub trzypiętrowych pałacach znajdujących się na dużych działkach (około jednego hektara). Zamożni ludzie musieli osiedlić się w "Budynkach Zamożnych" jedno-dwupiętrowych domach z działkami dziesięciokrotnie mniejszymi. "Budynkach Podłych" (rzemieślnicy, prywatni handlowcy itp.) z reguły przewidziano jednopiętrowe rezydencje z czterema pokojami znajdującymi się wokół pieca kaflowego (o powierzchni około $100 \mathrm{~m}^{2}$ ) (Rys. 3). Aby wspierać politykę zbliżenia przestrzennego obrazu mieszkania do ogólnych modeli europejskich, Cesarska Akademia Sztuki powstała w 1757 roku. Wkrótce nowe pokolenie rosyjskich architektów państwowych dołączyło do ogólnego kierunku architektury europejskiej (Brunov, 1951).

Zapożyczony obraz przestrzenny pałacu (ogromne pokoje, duże okna, nieuniknione strychy i piwnice) nie odpowiadał zbytnio stylowi życia miejskich gospodarstw domowych, dlatego urzędnicy państwowi zaczęli budować drugie mieszkanie poza miastem według tradycyjnych metod. W centrach miast pojawiły się budynki z ćwiartki wielokondygnacyjnej przypominającej ulice Wenecji i Florencji, a także na przedmieściach posiadłości w stylu antycznym. Poza kilkoma dużymi miastami reszta populacji (około $97 \%$ ) zajmowane średniowieczne formy mieszkań i zachowane tradycyjny wiejski styl życia. Pomimo stosunkowo wysokiego poziomu niejednorodności nowych i tradycyjnych mieszkań, różnice w właściwościach geometrycznych pomieszczeń wzrosły. Zakaz przenoszenia chłopów do miast wzmocnił tę tendencję.

Zniesienie chłopstwa naznaczone było rozszerzeniem przestrzennego wizerunku rosyjskiego mieszkania. W 1700 roku populacja miejska Imperium Rosyjskiego mogła wynosić około 400 tysięcy ludzi, a do 1914 roku osiągnęła 30,6 miliona (Federal State Statistics Service, 2006). W tym okresie architekci pozyskali nowych klientów. Właściciele biurowców, banków, firm przemysłowych 
i transportowych zaczęli wprowadzać nowe wymagania dotyczące organizacji pomieszczeń mieszkalnych. Edukacja architektoniczna przeniosła się z Cesarskiej Akademii Sztuk Pięknych do instytutów politechnicznych. Nowe pokolenie architektów, których wiedza została poszerzona o doświadczenie, zaczęło tworzyć przestrzenie o szerokiej gamie cech geometrycznych i właściwości budynków mieszkalnych.

Zniesienie chłopstwa w połowie XIX wieku i pozwolenie chłopom na osiedlenie się w rosyjskich miastach przyczyniły się do wzrostu przeludnienia pomieszczeń mieszkalnych i aktywnego rozprzestrzeniania się niehigienicznych warunków. W niektórych piwnicach nowych budynków mogło mieszkać nawet 20 osób. Jedna toaleta w budynku mogła być używana przez stu mieszkańców. Około 60\% ludności Petersburga mieszkało w domach o bardzo dużej gęstości zaludnienia (ponad 20 osób na lokal mieszkalny). Według niezweryfikowanych danych w Moskwie było około 13 tysięcy jednopokojowych mieszkań, w których mieszkało od 4 do 10 osób (Kozerenko, 1928). Podczas Pierwszej Wojny Światowej warunki życia w Europie gwałtownie się pogorszyły (Rys. 4).

Władze miasta Europy Zachodniej zmagały się z problemem przeludnienia wcześniej i zaczęły szukać rozwiązań poprzez zmiany organizacyjne. Oprócz chęci liberalnych i konserwatywnych polityków do znalezienia finansowych i technologicznych sposobów rozwiązania problemu mieszkaniowego, liderom ruchu komunistycznego udało się przekonać część społeczeństwa o potrzebie transformacji społecznej - "wyburzenie własności prywatnej rozwiąże problem mieszkaniowy" (Marks \& Engels, 1870). Oznaczało to, że nikt nie miał prawa do użytkowania gruntów i budynków jako środka dochodu. Wszystkie lokale mieszkalne w kraju miały być własnością państwa, które miało zapewnić kontrolę nad tempem budowy i jej dystrybucją. Żywność, odzież, mieszkania stały się sposobem na nagrodę rządu. Pojawiła się nowa koncepcja mieszkaniowej wszechstronnej przestrzeni mieszkalnej, w której pokój, jako główne miejsce spoczynku, był postrzegany wyłącznie jako sypialnia. Kuchnie, łazienki i toalety musieli być dostępne dla wszystkich. Z mieszkania miały zostać wyniesione czynności związane z edukacja czy przeprowadzaniem wolnego czasu.

\section{OKRESOWE ZMIANY W RADZIECKIM OBRAZIE PRZESTRZENNYM STANDARDOWEGO PREFABRYKOWANEGO MIESZKANIA}

Przyjęcie ustawy o całkowitej nacjonalizacji ziemi umożliwiło pod koniec 1917 r. przeniesienie całego majątku kraju w posiadanie władz terytorialnych. Chociaż wojna domowa uniemożliwiła wdrożenie reform społecznych, przywódcom kraju udało się sformułować główną zasadę polityki mieszkaniowej - "dążyć z całej siły do poprawy warunków życia mas pracujących"(Rubanenko, 1976). W wyniku wykonania dekretu $w$ sprawie konfiskaty prywatnych mieszkań miejskich na własność państwową, zasoby mieszkaniowe kraju zostały rozdzielone zgodnie z przyjętym standardem zamieszkania. Większość mieszkań miejskich zajmowało kilka gospodarstw domowych. Państwowa własność mieszkań miejskich umożliwiła również skuteczniejszą regulację procesu przekształcania mieszkań w zasoby niemieszkalne. Konieczność zapewnienia całej ludności kraju pełnego zatrudnienia doprowadziła do aktywnego korzystania z lokali mieszkalnych dla spółek skarbu państwa, co jeszcze bardziej pogorszyło warunki mieszkaniowe w miastach.

Marzenie większości chłopów o zamieszkaniu w miejskich mieszkaniach z łazienką i ciepłą wodą spełniło się niemal natychmiast. Powierzchnia mieszkalna na osobę w mieszkaniu w tym czasie w Rosji wynosiła około $4 \mathrm{~m}^{2}$. Potrzeba wspólnego zamieszkania rodziny spowodowała ogromna potrzebę nabycia oddzielnego mieszkania. Państwo postanowiło rozwiązać problem za pomocą małych mieszkań (1-2 pokoje o maksymalnej łącznej powierzchni $\left.30-50 \mathrm{~m}^{2}\right)$. Pierwsze próby wdrożenia domów z małymi pokojami ze wspólną kuchnią i pralniami okazały się nieodpowiednie, co doprowadziło do ich późniejszego wykorzystania jako biura.

Nowy obraz przestrzenny mieszkania w Paryżu, zaproponowany na paryskiej wystawie w 1922 roku przez Le Corbusiera, wydawał się spełniać wszystkie wymagania budowania państwowego. Gigantyczne drapacze chmur, położone w znacznej odległości od siebie, przypominały budynki dworskie, które wizualnie pokazały połączenie miasta i wsi. Jego proponowany plan odbudowy Moskwy zgodnie z tym przestrzennym obrazem nie został zaakceptowany ze względu na nadmierne koszty rozbiórki zabytkowych budynków (Rys. 5). 
Powolne tempo rozwoju gospodarczego zmusiło rząd radziecki do umożliwienia prywatnej przedsiębiorczości i powrotu do handlu rynkowego. Obawiając się pojawienia się nowej bogatej klasy klientów, co może doprowadzić do wyeliminowania idei powszechnej przestrzeni życiowej, do kontroli nad procesem projektowania stworzyli Związek Architektów Radzieckich i Akademię Architektury w 1934 roku. Od tego momentu rozwój przestrzenny kraju zaczął ponownie poddawać się poglądom politycznym. Mała społeczność architektów zaczęła szukać standardowych wzorów, które mogłyby być ponownie stosowane w całym kraju. Po II wojnie światowej zniszczone budynki Europy Wschodniej musiały zostać odbudowane. Gwałtowny wzrost powojennej populacji miejskiej zmusił państwo do zwiększenia tempa budowy. Niewielka liczba dużych państwowych firm budowlanych skupionych na tworzeniu wieżowców w dużych miastach miała na celu przede wszystkim rozwiązanie zadań ideologicznych i nie była w stanie zwiększyć wolumenu budowy.

Wyniki spisu ludności z 1959 r. wykazały, że zapewnienie ludności mieszkań nie uległo poprawie. Okazało się, że domy budowane zgodnie z projektami Akademii Architektury ZSRR są drogie. Był to początek ostrej krytyki pracy radzieckich architektów i oskarżeń o "marnotrawstwo i nadmierny entuzjazm" dla wystroju architektonicznego. Rząd postanowił przyjąć powojenne francuskie doświadczenie w taśmowej produkcji prefabrykowanych wielokondygnacyjnych budynków. Obliczenia ekonomiczne wykazały, że pod warunkiem, że takie fabryki budowy domów są budowane w głównych regionach kraju, koncentrujące się na budowie jednego standardowego typu domu przez 20 lat, byłoby wystarczające do osiągnięcia zgodności między liczbą mieszkań i liczby gospodarstw domowych w kraju. Prawo do opracowania projektu takiego domu przyznano centralnym instytutom projektowym. Po analizie ekonomicznej różnego rodzaju mieszkań wybrano pięciokondygnacyjny budynek z dziesięcioma małymi mieszkaniami wyposażonymi w zwartą kuchnię i jednostkę sanitarną. Ten rodzaj domu, opracowany podczas renowacji europejskich mieszkań po Pierwszej Wojnie Światowej, stał się również podstawą przestrzennego wizerunku mieszkań w Europie Wschodniej w XX wieku.

Pierwsze kompaktowe mieszkania w prefabrykowanych domach mieszkalnych masowej produkcji, które pojawiły się w ZSRR na początku lat 60 ., nie miały wystarczającej ilości miejsca, aby pomieścić rosnące artykuły gospodarstwa domowego. W latach 1963-1970 rząd był zmuszony zwiększyć wielkość powierzchni mieszkalnej standardowych mieszkań. Niska wydajność fabryk budowy domów i wysokie koszty dostarczania ciężkich wyrobów budowlanych okazały się kosztowne. Wzrost demograficzny, który wyprzedził tempo budowy, zaczął wpływać na wskaźnik urodzeń. Badania higieny potwierdziły negatywne skutki (choroby układu oddechowego, krążenia i trawienne) spowodowane życiem w małych, gęsto zaludnionych mieszkaniach. Stwierdzono również, że wpływ środowiska życia nie wpływa znacząco na narodziny pierwszego dziecka, jednak prawdopodobieństwo posiadania drugiego i trzeciego dziecka w dużej mierze zależy od warunków życia fizycznego i wpływa na jakość życia rodzinnego (Chaczatryants, 1968). Liczne badania z lat 80-tych wykazały również, że pomysły na jakość mieszkań wśród architektów i ludności były różne (Kruusvall, Heidemets, 1986). Mimo że typowe mieszkanie wyróżniały się dobrymi właściwościami operacyjnymi (miały kontrolę nad ciepłem, oświetleniem słonecznym i wentylacją) i posiadały minimalny zestaw niezbędnego sprzętu (piec do gotowania i niezbędny sprzęt instalacyjny), większość mieszkańców skarżyła się na nieodpowiedni rozkład przestrzeni w pomieszczeniach, rozmieszczenie drzwi i okien oraz parametry geometryczne pomieszczeń, które nie gwarantują komfortu ich życia.

Niezadowolenie ludności z wielkości mieszkania zaczęło spadać wraz ze wzrostem podaży mieszkań i zmniejszaniem się wielkości rodziny, ale nie zniknęły całkowicie, ponieważ zakres wymagań znacznie się rozszerzył w wyniku wzrostu różnorodności form życia. Na przykład rodziny samotnie wychowujących dzieci (mieszkające z jednym z rodziców) były skłonne poświęcić część swojej sypialni, aby uzyskać dodatkową łazienkę lub zmienić wejście do apartamentów. Stwierdzono, że wymagania dotyczące parametrów geometrycznych pomieszczeń są bezpośrednio zależne od cyklu życia i stanu zdrowia członków rodziny (Kiyanenko, 2005). Charakter użytkowania lokali mieszkalnych musiał również ulec zmianie w ramach rozwoju infrastruktury miejskiej, regionu klimatycznego i tradycji rodzinnych (Kartashova, 1985).

Pomimo ograniczeń technicznych, administracje wielu radzieckich miast zaczęły wprowadzać zautomatyzowany system zarządzania dystrybucją mieszkań, który umożliwił nieco uregulowanie róż- 
nic w warunkach życia. Średnia powierzchnia mieszkalna na mieszkańca w kraju stopniowo wzrastała i osiągnęła około $15,2 \mathrm{~m}^{2}$ w 1985 roku, co pozwoliło na szerszą geometryczną różnorodność mieszkań. Wymagało to jednak ponownego wyposażenia setek fabryk budowy domów, co okazało się niemożliwe ze względu na koszty związane z rozwojem infrastruktury inżynieryjnej. Tylko $12 \%$ podmiejskich budynków mieszkalnych miało ciepłą wodę i mogło fizycznie przybliżyć nowoczesne mieszkanie miejskie. Było to przyczyną zwiększonego odpływu ludności do miast i wzrostu liczby rodzin oczekujących na większe mieszkanie. Na przykład w L'vivprawie jedna czwarta rodzin czekała na przesiedlenie do nowego mieszkania (Derzhkomstat URSR,1991).

Rozwój mieszkań w oparciu o uniwersalny wizerunek mieszkania miejskiego o wąskim zakresie parametrów w warunkach całkowitej formy własności państwa nie mógł zapewnić niezbędnej różnorodności warunków życia w oparciu o rozszerzający się zakres wymagań spowodowanych dynamicznymi zmianami w stylu życia ludności (Durmanov, 1992). Aby bardziej dynamicznie reagować na zmieniające się wymagania dotyczące geometrycznych cech lokali mieszkalnych, państwo powinno mieć bardziej rozwinięty poziom rozwoju technologii informatycznych.

Chęć przeniesienia wszystkich pomieszczeń mieszkalnych Rosji na własność obywateli oznaczała porażkę polityki przestrzennej państwa. Nie oznaczało to natychmiastowego zniesienia ograniczeń geometrycznych w przepisach mieszkaniowych, niemniej jednak, dzięki włączeniu prywatnych inwestorów w proces odbudowy mieszkań, niemal natychmiast rozszerzyło różnorodność parametrów geometrycznych przestrzennego obrazu rosyjskich mieszkań. Mieszkania w centrach miast zaczęły być aktywnie kupowane i rekonstruowane. Zasoby mieszkaniowe w dużych miastach zostały wzbogacone o wieżowce i niskie domki. Wiele mieszkań zostało wynajętych niedokończonych dla właścicieli, aby zakończyć budowę ich zgodnie z ich wymaganiami. Różnorodność mieszkań wzrosła gwałtownie (Rys. 6).

Potrzeby mieszkaniowe zamożnych gospodarstw domowych zostały zaspokojone bardzo szybko. Sprzedaż na wtórnym rynku macierzystym spadła, ponieważ zakup nowego mieszkania oznaczał całkowitą lub częściową renowację mieszkania. Firmy budowlane musiały ponownie obniżyć parametry mieszkań do minimum i wynająć je w bardziej wykończonych. Trzydzieści lat po prywatyzacji, przestrzenny obraz nowego rosyjskiego mieszkania miejskiego powrócił do tradycyjnego kształtu, wielkości i organizacji planowania (Rys. 7).

Sto lat po wielkiej rewolucji październikowej całkowita powierzchnia mieszkalna Rosji wzrosła ponad 20 razy i osiągnęła $2,709 \mathrm{mln} \mathrm{m}^{2}$, podczas gdy liczba ludności wzrosła tylko 7 razy $(109,3$ tysiąca osób). Udział lokali prywatnych w miejskich zasobach mieszkaniowych w latach prywatyzacji wzrósł z $20 \%$ do więcej niż $90 \%$. Prywatne mieszkania zaczęły być wykorzystywane nie tylko do życia, ale także do wynajęcia. Udział domów zbudowanych z kapitałem prywatnym zaczął stopniowo rosnąć i wyniósł około $43 \%$, ale pomimo udziału zasobów ludności w modernizacji technicznej firm budowlanych, zmiana struktury lokali mieszkalnych w kraju przebiega powoli.

\section{PODSUMOWANIE}

Geometryczne cechy mieszkania w kraju są w trakcie ciąłej zmiany. Koncepcje poprawy jakości pomieszczeń mieszkalnych pojawiają się w społeczeństwie w wyniku świadomości niespójności pojawiających się w strukturze przestrzennego obrazu mieszkania. Kiedy gospodarstwo domowe zdaje sobie sprawę, że jego pożądane i rzeczywiste warunki życia przestają spełniać wysokiej jakości wydajność wdrożonych i planowanych procesów życiowych, stara się kierować wysiłki, aby go przekształcić. Jeśli taka transformacja jest niemożliwa z powodu ograniczeń gospodarczych, społecznych lub kulturowych, migracja staje się nieunikniona. W obliczu rosnącego niezadowolenia ludności z ich warunków życia, społeczeństwo będzie musiało ponownie przekształcić przestrzenny obraz mieszkań w oparciu o lokalne doświadczenia budowlane poprzez stymulowanie rozwoju badań nad swoimi mieszkaniowymi zasobami.

Istnieje kilka powodów zrównoważonego rozwoju reprodukcji przestrzennego obrazu rosyjskiego mieszkania miejskiego w ciągu ostatniego stulecia. Po pierwsze, znaczna część populacji (ponad 95\%) mieszka w domach zbudowanych w czasach sowieckich. Po drugie, architekci, z których 
większość widzi istotę zawodu w reprezentacji globalnych trendów stylistycznych w zewnętrznym wyglądzie budynku, nie zwracają uwagi na lokalne zmiany związane ze zmianą stylu życia. Po trzecie, firmy budowlane, w obliczu zwiększonego popytu na mieszkania, okazały się niezainteresowane znalezieniem nowej geometrii mieszkań związanych z rozwojem technologii projektowych, argumentując, że ludność nie potrzebuje zmiany geometrii mieszkań.

Ponadto pandemia pokazała, że nie można było utrzymać odległości społecznej w mieszkaniach o dużej gęstości, jednej sanitariacie i niemożności zainstalowania niezbędnego sprzętu medycznego. W krajach o wysokim poziomie edukacji komputerowej ludności i rozwiniętym systemie zdalnej kontroli medycznej ujawnił podstawowy niedobór pomieszczeń w mieszkaniach, aby zostawić chorych w domu. Wymuszona budowa tymczasowych szpitali nie rozwiązała problemu rozprzestrzeniania się epidemii w miastach. Najnowsze mutacje SOVID-19 pokazują, że wynalezienie szczepionki i poszukiwanie skutecznych pigułek nie jest jedynym sposobem na ratowanie życia, jak stało się znane po Czarnej Śmierci w Europie, która może ponownie aktualizować i udoskonalić zawód architekta.

\section{WNIOSKI}

1. Regularne obserwacje statystyczne rozwoju geometrycznych cech pomieszczeń mieszkalnych, rozpoczęte w drugiej połowie ubiegłego wieku, wykazują stopniowy wzrost średniej powierzchni, liczby pomieszczeń i sprzętu inżynieryjnego we wszystkich nowoczesnych krajach rozwiniętych. Chęć zwiększenia wielkości mieszkania odzwierciedla ogólną tendencję rozwoju społecznego związaną z potrzebą zwiększenia suwerenności przestrzennej prywatnych gospodarstw domowych, wyrażoną w dążeniu do większej fizycznej izolacji, niezależności i autonomii od środowiska.

2. Znaczące przekształcenia obrazu przestrzennego mieszkania miasta są obserwowane w okresach znaczących przemian społecznych. Wzrost różnorodności geometrycznej można prześledzić w okresach poszerzania praktycznego doświadczenia w budownictwie związanego z poszukiwaniem bardziej skutecznych lokalnych sposobów poprawy jakości pomieszczeń. Taka ekspansja nie zawsze prowadzi do poprawy jakości środowiska. Zwężenie zakresu parametrów w obrazie przestrzennym mieszkania obserwuje się wraz z rozszerzeniem wpływu informacji zewnętrznej. Pragnienie przybliżenia geometrycznych cech danego mieszkania do ogólnego obrazu przestrzennego można prześledzić w okresach ponownej oceny wartości społecznych. Zazwyczaj taka zmiana wynika ze spadku jakości mieszkań lokalnych w porównaniu z globalnym i wiąże się z zaufaniem do pożyczania historycznych lub społecznych doświadczeń bardziej rozwiniętej kultury

3. Informacyjny "zewnętrzny" wpływ oparty na pożyczaniu historycznego lub terytorialnego doświadczenia budowlanego oraz "wewnętrzny" związany z chęcią wdrożenia budowy w określonym środowisku produkcyjnym występuje jednocześnie. Wzmocnienie tej czy innego rodzaju formy wpływu jest zwykle konsekwencją świadomości negatywnych skutków spowodowanych przyjętym kierunkiem. Na rozwój wiedzy przestrzennej społeczeństwa ma wpływ równowaga homeostatyczna między konkretnymi koncepcjami empirycznymi i ogólnymi pojęciami globalnymi. Chociaż w ciągu ostatniego stulecia powstał globalny rynek nieruchomości, który zapewnił rozwój projektowania mieszkań na ścieżce dynamiki stylistycznej, poszukiwanie nowych form projektowania, które wykraczają poza estetyczny wpływ informacji wydaje się nieuniknione.

\section{BIBLIOGRAPHY}

Baker H. D., (2014). House Size and Household Structure: Quantitative Data in the Study of Babylonian Urban Living Conditions. Documentary sources in ancient Near Eastern and Greco-Roman economic history: methodology and practice. Oxbow Books, UK, p. 7-24

Blomkwist E. E., (1956). Krestjanskie postrojki ruskich ukraincew i belorusow [Peasant buildings of Russian, Ukrainians and Belarusians]: "Trudy instituta etnografii" V.XXXI Moscow, (in Russian)

Brunov H. I., (1951). Istoria Russkoj Architektury. [History of Russian architecture]: Gosstroyizdat, Moscow, p. 150. (in Russian) 
Bunin, A. V., (1979). Gradostroitelstwo rabowladelczeskogo stroja I feodalizma. [History of urban art: Urban planning of the slave system and feudalism]: Stroyizdat, Moscow, p. 323. (in Russian)

Derzhkomstat URSR, (1991. Zhitlovy fond I kwartyrnyj oblik u Ivivsmkij oblastij.[ Housing stock and accounting of apartments in the Lviv region]: Statistyczny zbirnik, Lviv, p. 45. (in Ukrainian)

Durmanov, V. Yu., (1992). Sotsial'naya osnova planirovochnogo razvitiya zhilishcha. [The social reason in the spatial development of housing units]: (Doctoral dissertation), Lviv, (in Russian)

Federal'naya sluzhba gosudarstvennoi statistiki. (2006). Rossiiskii statisticheskii ezhegodnik. Statisticheskii sbornik. [The Russian Federal State Statistics Service. Statistical The Yearbook of Russia. A Statistical Handbook. Official statistical publication issued by ROSSTAT]: Statistika Rossii. Moscow, pp. 81, 210, 480-481. (in Russian)

Kartashova, K. K., (1985). Formirovanie arkhitekturno-planirovochnoi struktury gorodskogo zhilishcha na sotsial'no-demograficheskoi osnove [Formation of the architectural and spatial structure of urban housing on a socio-demographic basis]: (Doctoral dissertation), Moscow. (in Russian)

Khachatryants, K.K., (1968). Voprosy projektirovania gorodskogo tipovogo zhilishcha s uczotom specyfiki zyznienogo układa sem'ji [lssues of designing an urban typical dwelling taking into account the specifics of the lifestyle of families]: (Dissertation), Minsk. (in Russian)

Kiyanenko, K. V., (1983). Tipologiczeskie osobennosti gorodskich kwartir dla prostych (nuklearnych) semej $\mathrm{s}$ detmi [Typological features of urban quartiles for simple (nuclear) families with children]: (Doctoral dissertation), Moscow. (in Russian)

Kozerenko N., (1928). Zylishnyj krizis I bor'ba s nim. [Housing crisis and the fight against it ]: Moscow, Leningrad: State Publishing House. (p.6, 30,89,215, 257,260,356). (in Russian)

Kruusvall J. \& Heidmets M., (1986.) O putiach powyshenia socialnoj effektivnosti zyloj sredy // Vosproizwodstwennyjie processy goroda. [On the ways to increase social efficiency in a residential environment // Reproduction processes in the city]: Tallinn, "Valgus", p.132. (in Russian)

Rappoport, P. A., (1993) Drevnierusskaja architektura [Old Russian architecture]: Stroyizdat, St. Petersburg. (in Russian)

Rubanenko B.R., (1976). Zylisznojie stroitelstwo w SSSR. [Housing construction in the USSR]: Moscow, Stroyizdat, p.4, (in Russian)

Lehmann J., (1998). Remarks concerning early Neolithic woodworking: The example of the bandkeramic well of Erkelenz-Kuckhoyen, Northerhine-Westfalia,Germany // Archeologia deell'Italia Settentrionale, N.7 p. 35-56

Marks, K. and Engels F., (1970). Izbrannyjie proizviedenia w 3-ch tomach [Selected works in 3 volumes]: Politizdat, Moscow. p. 354. (in Russian)

Pidoplichko I. G., (1969). Pozdniepaleoliticzeskojie zylishie iz kostej mamontow na Ukrainie. [Late Paleolithic dwellings made of mammoth bones in Ukraine]: Naukova Dumka, Kiev. (in Russian)

Terpilovsky R. V., (1994). Slavianie Poddnieprovja w pierwoj polowinie 1 tys.n.e. [Slavs of the Dnieper in the first half of the 1st millennium AD]: (Doctoral dissertation), Kiev. (in Russian)

\section{AUTHOR'S NOTE}

The Bialystok University of Technology, Doctor Habilitated (DSC), received an architectural education at the L'viv Polytechnic University in Ukraine, the Institute of Housing and the Institute of History and Theory of Architecture in Russia. Research Area: architecture and urban planning.

\section{O AUTORZE}

Uzyskał wykształcenie architektoniczne na Politechnice Lwowskiej na Ukrainie, Instytucie Mieszkalnictwa oraz Instytucie Historii i Teorii Architektury w Rosji. Obszar badawczy: architektura i urbanistyka. 